Berkala Ilmu Perpustakaan dan Informasi, Vol. 13, No. 1, Juni 2017, Hal. 1-11 DOI: http://10.22146/bip.26202

ISSN 1693-7740 (Print), ISSN 2477-0361 (Online)

Tersedia online di https://jurnal.ugm.ac.id/bip

\title{
PENGARUH MOTIVASI DAN KOMPETENSI TERHADAP KUALITAS LAYANAN PUSTAKAWAN
}

\author{
Anton Risparyanto \\ ${ }^{1}$ Pustakawan Universitas Islam Indonesia \\ e-mail: anton.risparyanto@yahoo.co.id
}

Naskah diterima: 10 April 2017, direvisi: 25 April 2017, disetujui: 12 Juni 2017

\begin{abstract}
ABSTRAK
Penelitian ini bertujuan untuk mengetahui pengaruh motivasi dan kompetensi terhadap kualitas layanan pustakawan secara sendirian (partial) maupun bersama (stimulan). Lokasi penelitian di Direktorat Perpustakaan Universitas Islam Indonesia. Data yang dikumpukan merupakan data primer dengan jumlah sampel sebanyak 29 responden. Data kuantitatif ditampilkan dalam bentuk tabel dan dianalisis dengan menggunakan statistik analisis jalur regresi berganda. Hasil penelitian ini menunjukkan bahwa; (1) pengaruh motivasi terhadap kualitas layanan pustakawan tidak signifikan dengan sumbangan relatif sebesar 12,5\%; (2) pengaruh komptensi terhadap kualitas layanan pustakawaan signifikan dengan sumbangan relatif sebesar 74,5\%; dan (3) secara bersama pengaruh motivasi dan kompetensi terhadap kualitas layanan pustakawan signifikan dengan sumbangan efektif sebesar $84,2 \%$.
\end{abstract}

Kata kunci: pustakawan, motivasi dan kompetensi terhadap kualitas layanan

\section{ABSTRACT}

This research aims to understand the influence of motivation and competence on the service quality of a librarian alone (partial) and in a group (stimulan). The research was conducted at the Directorate of Library of Islamic University of Indonesia with 29 librarians. Quantitative data was presented in tables and analyzed by using multiple regression path analysis statistics. The results showed that; (1) the influence of motivation on librarian service quality was not significant with relative contribution of $12.5 \%$; (2) the influence of the competence on the quality of librarian services was significant with the relative contribution of $74.5 \%$; and (3) when working in a group the influence of motivation and competence on librarian service quality was significant with effective contribution of $84.2 \%$.

Keywords: librarian, motivation and competence influence service quality

\section{A. PENDAHULUAN}

Kelancaran proses kegiatan belajar mengajar antara dosen dan mahasiswa selalu didukung oleh Perpustakaan. Perpustakaan merupakan agen berbagai jenis informasi yang dimanfaatkan oleh pemustaka yang membutuhkan. Dengan demikian pemustaka tidak akan merasa kesulitan dan cepat mendapatkan informasi yang tersedia di Perpustakaaan.

Sebagaimana disebutkan dalam dalam (Undang-Undang Republik Indonesia No. 43 tahun
2007 tentang Perpustakaan pada Bab I dalam pasal 1 ayat (1) dinyatakan bahwa : Perpustakaan merupakan suatu lembaga atau intitusi pengelola koleksi karya tulis, karya cetak, dan/atau karya rekam secara professional dengan sistem yang baku guna memenuhi kebutuhan pendidikan, penelitian, pelestarian, informasi, dan rekreasi para pemustaka. Dengan landasan peraturan tersebut mempunyai arti bahwa perpustakaan merupakan suatu lembaga atau intitusi pengelola informasi tercetak maupun non cetak (digital) yang harus dikelola secara 
professional yang berguna untuk kebutuhan pemustaka.

Dalam mengelola perpustakaan dibutuhkan tenaga professional yang sesuai dengan kompetensinya. Professi pustakawan memiliki kompetensi dalam bidang kepustakawanan yang diperoleh melalui pendidikan dan pelatihan. Seperti tercantum dalam pasal 1 ayat (8), bahwa pustakawan adalah seseorang yang memiliki kompetensi yang diperoleh melalui pendidikan dan/atau pelatihan kepustakawanan serta mempunyai tugas dan tanggung jawab untuk melaksanakan pengelolaan dan pelayanan perpustakaan. Kompetensi pustakawan yang dimaksud pada pada Bab VIII dalam pasal 29 ayat (1) dan ayat (2) harus memenuhi standar kualifikasi sesuai dengan standar nasional. The Special Library Association menyebutkan bahwa kompetensi pustakawan dibedakan menjadi dua yaitu: kompetensi professional dan kompetensi personal. Kompetensi profesional merupakan kompetensi yang berkaitan dengan keahlian, pengetahuan dan keterampilan pustakawan di bidang ilmu perpustakaan dan informasi. Sedangkan kompetensi personal merupakan keahlian dan keterampilan yang dimiliki oleh setiap pustakawan, sehingga dapat dinyatakan bahwa kompetensi personal meruakan kemampuan seorang pustakawan dalam melaksanakan kegiatan kepustakawanan yang timbul karena adanya dorongan dalam dari sendiri maupun pengaruh dari faktor luar.

Kompetensi akan dapat membangun kualitas layanan prima di perpustakaan apabila pustakawan meningkatkan kompetensinya (Daryono, 2010). Dengan demikian dapat diartikan bahwa kompetensi professional pustakawan akan berpengaruh terhadap kualitas layanan pustakawan. Penelitian yang lain berkaitan dengan kompetensi juga menyatakanbahwa peningkatan kompetensi akan berpengaruh terhadap sikap/perilaku pegawai yang mengarah pada peningkatan kinerja pustakawan (Sampe, 2014). Merujuk pernyataan di atas dapat diartikan bahwa kompetensi pustakawan mempunyai pengaruh terhadap motivasi pustakwan atau kualitas layanan pustakawan. Kualitas layanan juga sangat erat kaitannya dengan motivasi pustakawan. Motivasi yang baik akan mendukung kualitas layanan pustakawan. Begitu pula sebaliknya, apabila motivasi pustakawan kurang, maka akan kurang juga kualitas layanan atau kinerja pustakawan. motivasi pustakawan juga mempunyai peran sangat penting dalam meningkatkan kualitas layanan.
Apabila dipadukan menjadi satu dalam satu pembahasan, maka tiga pokok masalah antara motivasi pustakawan, kompetensi pustakawan dan kulitas layanan pustakawan akan terjadi korelasi yang saling mempengaruhi antara variabel independent dengan variabel dependent. Variabel motivasi dan kompetensi pustakawan (independent) secara sendirian (partial) maupun bersama (simultan) akan berpengaruh terhadap kualitas layanan pustakawan. Apabila motivasi dan kompetensi pustakawan baik maka kualitas layanan pustakawan akan baik, dan mempunyai sumbangan yang besar terhadap kualitas layanan yang dilakukan pustakawan. Hal ini terjadi dari akibat dari meningkatnya motivasi dan kompetensi pustakawan yang semakin baik. Berpijak pada latar belakang permasalahan sebagaimana tersebut di atas, maka rumusan masalah dalam penelitian dinyatakan sebagai berikut: (1) apakah signifikan pengaruh motivasi terhadap kualitas layanan pustakawan; (2) apakah signifikan pengaruh kompetensi terhadap kualitas layanan pustakawan; (3) secara simultan, apakah signifikan pengaruh motivasi dan kompetensi terhadap kualitas layanan pustakawan; dan (4) berapa sumbangan efektif serta relatif masing-masing motivasi dan kompetensi terhadap kualitas layanan pustakawan.

Penelitian ini dilakukan dengan tujuan untuk mengukur pengaruh serta sumbangan motivasi kerja dan kompetensi profesional terhadap kualitas layanan secara sendirian (parsial) maupun bersama (stimultan). Disamping itu penelitian ini diharapkan bermanfaat untuk memberikan masukan terhadap pimpinan lembaga dalam masalah: (1) perumusan konseptual pengembangan kualitas layanan pustakawan Universitas Islam Indonesia di masa akan datang; (2) pengelolaan motivasi dan kompetensi pustakawan dalam rangka meningkatkan kualitas layanan pustakawan; dan (3) sebagai bahan pertimbangan pimpinan dalam meningkatkan kualitas layanan pustakawan melalui motivasi dan kompetensi pustakawan.

\section{B. TINJAUAN PUSTAKA}

Ada hubungan erat dan saling berpengaruh antara motivasi dan kemampuan (kompetensi) kerja terhadap kualitas layanan seorang pegawai dalam suatu perusahaan. Hubungan maupun pengaruh antara motivasi dan kemampuan kerja tersebut, seringkali menentukan besarnya tingkat kualitas layanan di perusahaan maupun tempat layanan jasa. Masalah tersebut telah dibahas oleh para peneliti sebelumnya dengan menyatakan adanya pengaruh 
signifikan antara motivasi kerja terhadap kualitas layanan pegawai (Ajis, 2008). Selain itu penelitian yang lain juga menunjukkan bahwa terdapat pengaruh signifikan antara motivasi dan kemampuan (competence) kerja (mengajar) terhadap kualitas layanan, baik secara individual (partial) maupun simultan (Supriyanto, 2011). Secara bersama pengaruh motivasi dan kempampuan kerja terhadap kualitas layanan signifikan, sedangkan secara parsial motivasi kerja pengaruhnya tidak signifikan dan kemampuan kerja mempunyai pengaruh signifikan terhadap kualitas layanan (Samosir, 2006).

Masalah penelitian sebelumnya pada jasa perawat dan profesi dosen telah dinyatakan adanya pengaruh signifikan motivasi dan kompetensi professional terhadap kualitas jasa layanan. Semakin tinggi motivasi pustakawan dalam menyelesaikan berbagai persoalan pekerjaan yang didukung dengan kemampuan komptensi profesional yang memadai akan menghasilkan kualitas layanan jasa yang baik dan mempunyai nilai kerja signifikan terhadap kualitas layanan jasa informasi. Artinya motivasi dan kompetensi profesional secara parsial maupun stimulat mempunyai pengaruh terhadap kualitas layanan jasa pustakawan.

Pengaruh motivasi kerja dan komptensi professional pustakawan terhadap kualitas layanan jasa informasi akan diuraikan melalui tiga variabel yang saling berhubungan guna memperjelas permasalahan sehingga tidak menimbulkan penafsiran yang salah. Setiap variabel akan menjelaskan secara rinci definisi, dimensi dan karateristik yang dimiliki, ketiga variabel tersebut sebagai berikut:

\section{a. Kualitas Layanan Pustakawan}

Sebagai tenaga pengelola perpustakaan, pustakawan mempunyai tugas melakukan layanan jasa informasi terhadap pelanggan (pemustaka). Kualitas layanan pustakawan dalam melakukan layanan jasa terhadap pelanggan sangat diperlukan.

Kualitas jasa merupakan suatu pemenuhan kebutuhan dan keinginan pelanggan serta ketepatan penyampaian mengimbangi harapan pelanggan (Fandy Tjiptono, 2003). Apabila jasa informasi dapat memenuhi kebutuhan pemustaka, maka akan merasa puas sesuai dengan yang diharapkan. Jika jasa yang memberi melebihi dari yang diterimakan, maka kualitas jasa dapat dikatakan ideal. Tetapi sebaliknya apabila pustakawan tidak dapat memenuhi sesuai kebutuhan informasi pemustaka, maka kualitas jasa yang diberikan mempunyai persepsi buruk. Jika demikian pemenuhan jasa informasi terhadap pemustaka tergantung dari kualitas layanan pustakawan.

Kualitas layanan pustakawan terhadap pemustaka dapat meningkat melalui berbagai langkah, sehingga pemustaka akan mendapatkan kepuasan. Salah satu langkah tersebut diantaranya melalui kontak person langsung antara pustakawan dan pemustaka. Kontak person (contact personnel) pustakawan dengan pemustaka ini sangat menentukan kualitas layanan jasa perpustakaan. Dengan demikian pustakawan telah berusaha melakukan layanan unggul (service excellence) terhadap pemustaka, yaitu suatu sikap karyawan dalam melayani pelanggan secara memuaskan (Elhaitamy dalam Fandy Tjiptono , 2003). Ada empat langkah agar dapat melakukan layanan pelanggan bermutu atau berkualitas antara lain:

1. Menyampaikan sikap positip kepada pelanggan, sehingga mempunyai kesan awal yang baik kepada pelanggan.

2. Mengenali kebutuhan pelanggan yang sesuai yang diinginkan.

3. Memenuhi kebutuhan pelanggan, sehingga kebutuhan pelanggan terpenuhi.

4. Pastikan pelanggana akan kembali lagi, sehingga menjadi partner kita.

Hasil penelitian khusus jasa yang dilakukan oleh beberapa pakar seperti (Parasurahman, Zeithhaml dan Berry dalam Fandy Tjiptono, 2003) telah berhasil melakukan identifikasi terhadap sepuluh faktor yang dapat meningkatkan kulaitas jasa anatara lain:

1. Peralatan dan ruang kerja yang tertata rapi akan kelihatan menarik serta yaman merupakan wujud dari layanan pustakawan.

2. Kerja secara efektif dan benar merupakan kehandalan dari pada kinerja pustakawan.

3. Memberi jawaban pertanyaan dengan tepat mencarikan solusi dalam waktu singkat merupakan salah satu tanggapan (responsiveness) pustakawan terhadap pemustaka.

4. Kompetensi yang dimiliki pustakawan dapat memberikan kepuasan layanan terhadap pemustaka.

5. Kemudahan akses informasi yang tersedia sehingga menyenangkan pemustaka, merupakan sarana komunikasi efektif dalam melakukan pelacakan informasi sesuai kebutuhan pemustaka. 
6. Cepat tanggap, sopan santun, ramah, bershabat merupakan sifat perilaku (courtesy) seorang pustakawan.

7. Kemampuan mendengarkan dan menyerap aspirasi merupakan komunikasi yang baik antara pustakawan dan pemustaka.

8. Sifat kejujuran (creadibility) merupakan meningkatkan nilai integritas profesi pustakawan.

9. Kenyamanan, keamanan dan keselamatan pemustaka selama di perpustakaan harus dapat terjamin dengan baik.

10. Pustakawan harus mampu menggali, memahami dan memenuhi kebutuhan pemustaka secara baik.

\section{b. Kompetensi Pustakawan}

Kompetensi pada dasarnya merupakan ketrampilan, pengetahuan, keahlihan, kemampuan yang berhubungan dengan tingkat kinerja suatu pekerjaan seperti pemecahan masalah, pemikiran analitik dan kepemimpinan yang harus dimiliki seseorang dalam memegang jabatan (Depnakertrans dalam Titiek Kismiyati, 2011). Kesiapan sertifikasi pustakawan, Media pustaka 2011 18(3\&4):13-18. Menurut The Special Library Association (dalam Rachman Hermawan \& Zulfikar Zen, 2006) kompetensi professional yang harus dimiliki setiap pustakawan antara lain:

1. Memiliki ketrampilan, keahlian, mengidentifikasi, menganalisis dan mengavaluasi sumber-sumber informasi secara kritis dan baik.

2. Memiliki pengetahuan luas tentang subjek guna melakukan organisasi informasi sesuai bidang topik yang dibutuhkan prmustaka.

3. Membuat konsep pengembangan dan pengelolaan informasi dengan baik sehingga dapat diakses secara mudah (accessable) serta efektif dalam pembiayaan(cost-effective) yang sejalan dengan sistem organisasi.

4. Melakukan bimbingan dan bantuan terhadap pemustaka.

5. Melakukan prediksi jenis dan kebutuhan informasi, nilai jual dan produk informasi yang dihasilkan.

6. Dapat memanfaatkan teknologi informasi guna melakukan layanan teknis perpustakaan dan penyebaran informasi.

7. Mampu menangkap peluang bisnis infomasi dan mengkomunikasikan kepada manajer senior tentang pentingnya layanan informasi.
8. Dapat mengembangkan produk-produk informasi khusus yang dapat digunakan oleh lembaga tertentu.

9. Melakukan evaluasi hasil pemanfatan informasi serta melakukan riset yang berhubungan dengan masalah-masalah manajemen informasi.

10. Secara kontinuitas melakukan perbaikan layanan informasi guna melakukan respon terhadap perubahan kebutuhan pengguna.

11. Masuk anggota tim manajer senior secara efektif dan menjadi konsultan organisasi di bidang informasi.

Pengelompokan kompetensi pustakawan di atas pada dasarnya sesuai dengan peneliti lain yang menyatakan bahawa" kompetensi profesional berhubungan dengan pengetahuan yang dimiliki mengenai hal sumber-sumber informasi, metode akses informasi, kompetensi mendayagunakan sarana teknologi Informasi berupa perangkat lunak (software), keras (hardware) dan menajemen informasi yang dikelompokkan menjadi beberapa dimensi diantaranya: 1) susunan organisasi informasi; 2) susunan sumber-sumber informasi; 3) aturan layanan informasi; dan 4) melakukan implementasi "alat" teknologi informasi. Sedangkan kompetensi perorangan meliputi ketrampilan, keahlian, sikap dan nilai yang dapat mewujudkan kinerja pustakawan secara efisien dan sumbangsih positif bagi profesi, institusi dan pengguna perpustakaan, dimulai menjadi komunikator yang baik, untuk dapat menunjukkan nilai tambah atas karyanya dan selalu berpikir positif dan fleksibel atas berbagai perubahan di lingkungan perpustakaan. Kesemuanya itu terangkum dalam kompetensi inti (core competencies) dimana terdapat kemampuan dasar yang harus dimiliki seorang pustakawan (Wiratna Tritawirasta, 2010).

\section{c. Motivasi Pustakawan}

Pengelolaan berbagai jenis perpustakaan yang dilakukan oleh setiap pustakawan, memerlukan berbagai macam aktifitas kegiatan, yang dimulai dari pengadaan bahan pustaka yang akan digunakan sebagai bahan koleksi perpustakaan, pengolahan, pengawetan, pelestarian dan penyajian kepada pemustaka. Bahan pustaka tersebut meliputi bahan cetak maupun non cetak (Lasa Hs., 2009).

Aktivitas kegiatan yang dilakukan oleh setiap pustakawan merupakan suatu keinginan atau darongan yang bangkit atau timbul dari dalam diri (intrisik) maupun dari luar (ekstrisik) pustakawan. Keseluruhan dorongan keinginan, kebutuhan, dan 
yang sejenisnya merupakan suatu istilah umum yang disebut motivasi. Sedangkan suatu dorongan yang timbul dari dalam maupun dari luar merupakan motivasi instrisik dan ekstrisik sesuai dengan kebutuhan seseorang. Dalam bidang perpustakaan motivasi intrisik tersebut diantaranya adanya suatu keinginan seorang pustakawan untuk melakukan aktivitas yang dapat menghasilkan gaji (kompensasi) untuk memenuhi kebutuhan ekonomi. Sedangkan dorongan eksternal, seperti adanya suatu keinginan untuk mengembangkan karir pustakawan yang lebih tinggi.

Berdasarkan penjelasan diatas, kita dapat mendefinisikan motivasi pustakawan yaitu merupakan dorongan yang terdapat pada diri seorang pustakawan untuk mengelola atau melakukan kegiatan kepustakawanan pada unit perpustakaan, dokumentasi dan informasi. Motivasi pustakawan terjadi karena adanya faktor intrisik mapun ekstrisik, sehingga pustakawan dapat berprestasi dengan baik, penuh tanggung jawab, mandiri dan mempunyai kemampuan yang selalu berkembang dalam meningkatkan kenerja pustakawan.

\section{d. Hipotesis Penelitian}

Dalam perumusan hipotesis peneliti membuat beberapa asumsi adanya hubungan antara motivasi dan komptensi pustakawan terhadap kualitas layanan pustakawan. Berdasarkan asumsi ini dapat dirumuskan hipotesis sebagai berikut:

Hla: Motivasi secara parsial tidak berpengaruh terhadap kualitas layanan pustakawan.

H1b: Pengaruh motivasi terhadap kualitas layanan pustakawan secara parsial signifikan.

H2a: Kompetensi secara parsial tidak berpengaruh terhadap kualitas layanan pustakawan.

H2b: Pengaruh kompetensi terhadap kualitas layanan pustakawan secara parsial signifikan.

H3a: Motivasi dan kompetensi secara stimulat tidak berpengaruh terhadap kualitas layanan pustakawan.

H3b: Pengaruh motivasi dan kompetensi terhadap kualitas layanan pustakawan secara stimulat signifikan.

\section{METODE PENELITIAN}

Metode yang digunakan dalam penelitian yaitu melalui survei data dengan menggunakan alat kuesioner sebagai alat pengambilan data pada sampel yang terdapat dalam populasi. Pengambilan data dilakukan terhadap 29 responden pustakawan Direktorat Perpustakaan Universitas Islam Indonesia, dengan pertimbangan perpustakaan perguruan tinggi telah menerapkan sistem jabatan fungsional pustakawan dengan baik. Data yang terkumpul adalah merupakan data primer yang diperoleh langsung dari pustakawan. Data dianalisis secara kuantitatif dengan menggunakan beberapa table hasil olahan bantuan SPSS.

Analisis data yang digunakan adalah regresi berganda. Secara matematis persamaan tersebut adalah sebagai berikut:

$$
\mathrm{Y}=\beta 0+\beta_{1} \boldsymbol{X}_{1}+\beta_{2} \boldsymbol{X}_{2}+\mathrm{e}
$$

Keterangan :

$$
\begin{gathered}
\begin{array}{c}
\beta_{0}, \beta_{1}, \beta_{2}=\text { Koefisien } \\
\mathrm{Y}
\end{array} \\
\begin{array}{c}
\text { Kualitas layanan pustakawan (variabel } \\
\text { dependent) }
\end{array} \\
\mathrm{X}_{1}=\begin{array}{l}
\text { Kompetensi professional (variabel } \\
\text { independent) }
\end{array} \\
X_{2}=\begin{array}{c}
\text { Motivasi kerja pustakawan (variabel } \\
\text { independent) }
\end{array} \\
\mathrm{e} \quad \text { ErrorTerm }
\end{gathered}
$$

Uji hitpotesis yang digunakan dalam penelitian ini yaitu: (1) Uji hipotesis F untuk menguji pengaruh nilai signifikan variabel independent-secara serempak terhadap variabel dependent (menguji keberartian koefisien regresi ganda secara simultan dengan prosedur sebagai berikut: Variabel independent mempunyai pengaruh secara serempak, apabila nilai signifikan $\mathrm{F}$ hitung lebih kecil dari pada 0.05 atau $(0.05<$ Sig) Sebaliknya apabila nilai signifikan $\mathrm{F}$ hitung lebih besar dari pada 0.05 atau $(0.05>\mathrm{Sig})$, maka variabel independent secara serempak tidak berpengaruh terhadap variabel dependent dan (2) Uji Hipotesa t untuk mengetahui pengaruh parsial variabel independent terhadap variabel dependent-dengan prosedur sebaagai berikut: Variabel independent mempunyai pengaruh secara parsial, apabila nilai signifikan (t) hitung lebih kecil dari pada 0.05 atau $(0.05>$ Sig). Sebaliknya apabila nilai signifikan $(\mathrm{t})$ hitung lebih besar dari pada 0.05 atau $(0.05<\mathrm{Sig})$, maka variabel independent secara parsial tidak berpengaruh terhadap variabel dependent.

Uji korelasi digunakan untuk mengetahui besarnya konstribusi atau pengaruh varibel independent $(\mathrm{X})$ terhadap varibel dependen $(\mathrm{Y})$ secara serempak (simultan) maupun masing-masing variabel (parsial). Pengukuran ini melihat besarnya determinan $\left(\boldsymbol{R}^{2}\right)$, yaitu angka yang menunjukan 
berapa \% (proporsi) pengaruh variabel independent terhadap variabel dependent. Sedangkan sisanya sekian \% dipengaruhi oleh berbagai faktor lain yang tidak dapat dijelaskan dalam variabel penelitian ini. Kekuatan hubungan antara variabel bebas dan terikat secara metematis dapat dihitung dengan menggunakan persamaan matematis:

$\boldsymbol{R}^{2}=\frac{\sum\left(\dot{\mathrm{Y}}_{i}-\mathrm{Y}\right)^{2}}{\sum\left(\mathrm{Y}_{i}-\mathrm{Y}\right)^{2}}=\frac{E S S}{T S S}=\frac{\sum y i^{2}}{\sum y i^{2}}=\frac{\beta_{1}^{2} \sum x_{i}^{2}}{\sum y_{i}^{2}}=\beta_{1}^{2}\left(\frac{\sum x_{i}^{2}}{\sum y_{i}^{2}}\right)$

Keterangan: $\mathrm{R}$ = besarnyahubungan

$\mathrm{X}_{1}=$ Variabel independent

$\mathrm{X}_{2}=$ Variabel independent

$\mathrm{Y}=$ Variabel dependent.

Variabel penelitian ini terdiri dari motivasi kerja dan kompetensi profesional pustakawan yang mempunyai fungsi sebagai variabel bebas yang akan mempengaruhi kualitas layanan pustakawan sebagai variabel terikat.

\section{HASIL DAN PEMBAHASAN \\ a. Analisis Statistik Deskriptif}

Dalam penelitian ini analisis statistik deskriptif menggunakan nilai rata-rata dan standar deviasi. Hasil analisis statistik deskriptif dalam penelitian ini dapat dilihat dalam tabel 1:

Tabel 1

Deskripsi Variabel Motivasi, Kompetensi dan Kualitas Layanan Pustakawan

\begin{tabular}{cccccccccccc}
\hline & \multicolumn{1}{c}{ Pustakawan } \\
\cline { 2 - 11 } Keterangan & \multicolumn{1}{c}{ Motivasi } & \multicolumn{2}{c}{ Kompetensi } & \multicolumn{3}{c}{ Kualitas layanan } \\
\cline { 2 - 11 } & Interval & $\%$ & $\mathrm{~N}$ & Interval & $\%$ & $\mathrm{~N}$ & Interval & $\%$ & $\mathrm{~N}$ \\
\hline Sangat jelek & $43-46$ & 17 & 5 & $64-70$ & 31 & 9 & $54-59$ & 34 & 10 \\
Jelek & $47-50$ & 38 & 11 & $71-77$ & 17 & 5 & $60-65$ & 24 & 7 \\
Baik & $51-54$ & 14 & 4 & $78-84$ & 35 & 10 & $66-71$ & 28 & 8 \\
Sangat baik & $55-60$ & 31 & 9 & $85-91$ & 17 & 5 & $72-77$ & 14 & 4 \\
\hline Rata-rata & 50 & & & 77 & & & 64 &
\end{tabular}

Sumber: Data Primer Hasil Olahan, Tahun 2015

Hasil analisis data yang diambil dari 29 pustakawan sebagaimana tercantum pada tabel 1 dijelaskan sebagai berikut : (1) nilai rata-rata untuk variabel motivasi pustakawan sebesar 50 diantara interval 47-50, sehingga dapat disimpulkan bahwa motivasi pustakawan ratarata jelek; (2) nilai rata-rata untuk variabel kompetensi pustakawan sebesar 77 diantara interval 71-77, sehingga dapat disimpulkan bahwa kompetensi pustakawan rata-rata jelek; (3) dan nilai rata-rata untuk variabel kualitas layanan pustakawan sebesar 64 diantara interval 66-65, sehingga dapat disimpulkan kualitas layanan pustakawan rata-rata jelek.

\section{a. Regresi Linier Berganda.}

Berdasarkan hubungan antara variabel bebas dan terikat. besarnya motivasi dan kompetensi sebagai variabel bebas sangat berpengaruh terhadap besarnya kualitas layanan pustakawan berfungsi sebagai variabel terikat. Hasil olah data analisa jalur regresi berganda dengan bantuan program SPSS tampak pada tabel 2 .

Tabel 2

Koefisien Jalur

Kontribusi Langsung dan Tidak Langsung, Kontribusi Efektif dan Relatif

\begin{tabular}{cccccc}
\hline \multirow{2}{*}{ Variabel } & Koefisien jalur & \multicolumn{3}{c}{ Sumbangan relatif } & \multicolumn{2}{c}{$\begin{array}{c}\text { Sumbangan } \\
\text { efektif=simultan }\end{array}$} \\
\cline { 3 - 6 } & & Langsung & $\begin{array}{c}\text { Tidak } \\
\text { Langsung }\end{array}$ & Total & \\
\hline Motivasi= $\mathrm{X}_{1}$ & 0,125 & 0,125 & - & 0,125 & - \\
\hline Kompetensi= $\mathrm{X}_{2}$ & 0,748 & 0,748 & - & 0,748 & - \\
\hline $\mathrm{a}$ & 0,397 & 0.158 & - & & - \\
\hline $\mathrm{X}_{1}$ dan $\mathrm{X}_{2}$ & - & - & - & & 0,842 \\
\hline
\end{tabular}

Pada tabel 2 tertera besarnya nilai konstata dan koefisien yang mewakili pembentuk persamaaan regresi ganda pengaruh variabel bebas (motivasi dan kompetensi pustakawan) terhadap variabel terikat (kualitas layanan) sebagai berikut:

$\hat{\mathrm{Y}}=\mathrm{a}+\mathrm{b}_{1} \mathrm{X}_{1}+\mathrm{b}_{2} \mathrm{X}_{2}=0,397+0,125 \mathrm{X}_{1}+0,748 \mathrm{X}_{2}$

Keterangan:

$\mathrm{X} 1=$ Motivasi pustakawan

$\mathrm{X} 2=$ Kompetensi pustakawan

$\hat{\mathrm{Y}}=$ Kualitas layanan pustakawan

Hasil analisis regresi linier berganda $\hat{Y}=0,397+$ $0,125 \mathrm{X}_{1}+0,748 \mathrm{X}_{2}$ mempunyai arti bahwa:

1. Konstanta $=0,397$ 
2. Berdasarkan persamaan regresi linier diatas, maka dapat diinterprestasikan bahwa nilai konstata 0,397 mempunyai arti bahwa konstata sebesar 0,397 merupakan nilai kualitas layanan akan tetap apabila kenaikan nilai motivasi kerja dan kompetensi professional tidak ada kenaikan atau sama dengan nol.

3. Koefisien motivasi pustakawan $=0.125$

4. Motivasi kerja berpengaruh positif tidak signifikan terhadap kualitas layanan 0.125 mempunyai arti setiap terjadi kenaikan satu nilai motivasi kerja maka akan memberikan nilai sebesar 0.125 dengan anggapan variabel kompetensi pustkawan tetap (konstan).

5. Koefisien kompetensi pustakawan sebesar 0,748

6. Kompetensi pustakawan berpengaruh positif signifikan terhadap kualitas layanan pustakawan dengan kontanta 0,748 mempunyai arti apabila terjadi kenaikan kompetensi pustakawan satu kali, maka kulitas layanan akan naik 0,748 dengan anggapan variabel motivasi pustakawan konstan.

\section{b. Sumbangan Efektif Terhadap Kualitas Layanan}

Kualitas layanan pustakawan di perpustakaan ditentukan oleh sumbangan efektif yang mempunyai peran penting dalam menentukan baik dan buruknya suatu layanan. Sumbangan efektif tersebut yaitu variabel independent $(\mathrm{X})$ terdiri dari: variabel $\left(\mathrm{X}_{1}\right)$ motivasi pustakawan dan variabel $\left(\mathrm{X}_{2}\right)$ kompetensi pustakawan secara bersamaan memberi sumbangan terhadap variabel dependent (Y) kualitas layanan pustakawan. Besarnya sumbangan efektif tertera pada tabel 2 sebesar 84,2\%. Artinya masih ada 15,8\% faktor lain di luar variabel independent yang ikut menentukan besarnya sumbangan terhadap kualitas layanan pustakawan. Adapun variabel lain yang ikut menentukan sumbangan terhadap kualitas layanan tersebut menurut Abraham $\mathrm{H}$. Maslow (1994) yaitu adanya kebutuhan dasar manusia yang harus dipenuhi untuk mendapatkan kepuasan hidup diantaranya: makan, minum, tempat tinggal, seks, kenyamanan, keamanan, kasih sayang keluarga dan kehidupan bermasyarakat. Selain itu Anok Herdian Dito (2010) juga mengatakan motivasi kerja karyawan dapat ditingkatkan melalui pemberian kompensasi terhadap karyawan yang memiliki kenerja bagus. Artinya kompensasi kinerja berpengaruh positif dan signifikan terhadap motivasi kerja karyawan.

Sedangkan pada penelitian ini aspek kualitas layanan pustakawan akan dikupas melalui dimensi layanan berkualitas dengan ciri-ciri antara lain: bukti fisik (tangibles), kehandalan (reliability), daya tanggap (responsive), jaminan (assurance) dan empati (empathy). Data pada tabel 1, hasil observasi dari 29 responden menyebutkan: 8 pustakawan (28\%) dapat melakukan layanan dengan baik, serta 4 pustakawan (14\%) sangat baik. Sedangkan sisanya 7 pustakawan $(24 \%)$ melakukan layanan jelek, bahkan 10 pustakawan (34\%) lebih jelek lagi dalam melakukan layanan pada pemustaka.

Melihat data temuan di lapangan, dapat diinterprestasikan bahwa 17 pustakawan (58\%) melakukan layanan jelek terhadap pemustaka. Sedangkan pustakawan yang dapat melakukan layanan dengan baik hanya 8 pustakawan (28\%), data ini ada 4 pustakawan (14\%) dapat melakukan layanan dengan sangat baik, yaitu pustakawan ahli pendidikan S2 yang memiliki kompetensi ilmu perpustakaan dan informasi dengan baik.

Aspek kompetensi pustakawan akan digali melalui beberapa faktor seperti: pengembangan koleksi yang tersedia, pemrosesan bahan pustaka sebelum dilayankan, transasksi layanan terhadap pemustaka, pencarian literasi informasi dan pelestarian bahan pustaka. Hasil data olahan tertera pada tabel 1, sebanyak 29 responden mempunyai kompetensi sebagai berikut: 10 pustakawan $(35 \%)$ baik, serta 5 pustakawan $(17 \%)$ sangat baik. Sedangkan sisanya 5 pustakawan (17\%) kompetensi yang dimiliki jelek dan 9 pustakawan (31\%) lebih jelek lagi kompetensi yang dimiliki. Data hasil observasi dilapangan dapat disimpulkan bahwa, pustakawan yang memiliki kompetensi baik 
lebih dari 50\%, hal ini disebabkan adanya pembinaan pustakawan dengan malalui berbagai kegiatan diantaranya workshop dan seminar kepustakawanan.

Sedangkan aspek motivasi pustakawan akan diungkap melalui prestasi kerja yang baik, selalu bertanggung tanggung jawab dalam melaksanakan tugas, kemandirian dan mempunyai keinginan untuk mengembangkan diri. Hasil olah data yang tertera pada tabel 1 dari 29 responden menyatakan: 4 pustakawan (14\%) memiliki motivasi baik, serta 9 pustakawan (31\%) sangat baik. Sedangkan sisanya 11 pustakawan (38\%) motivasinya jelek dan 5 pustakawan (17\%) sangat jelek. Berdasarkan data penelitian ini dapat disimpulkan bahwa sebanyak 16 pustakawan (55\%) motivasinya jelek.

Melihat sumbangan efektif variabel independent $\mathrm{X}$ sebesar $84,2 \%$, ini mengindikasi variabel motivasi dan kompetensi pustakawan secara bersamaan mempunyai pengaruh signifikan terhadap kualitas layanan pustakawan. Nilai signifikan tersebut tampak pada tabel 3 yang menunjukkan nilai $\mathrm{F}$ hitung sebesar 31,556 dengan probabilitas signifikan (F) hitung lebih kecil dari pada 0.05 atau (Sig $<0.05)$. Nilai ini memcpunai arti, secara bersamaan variabel independent (motivasi dan kompetensi pustakawan) mempunyai pengaruh signifikan terhadap kualitas lay.anan pustakawan.

Tabel 3 Uji Signifikan F

\begin{tabular}{|c|c|c|c|c|c|c|}
\hline \multicolumn{2}{|c|}{ Model } & $\begin{array}{c}\text { Sum of } \\
\text { Squares }\end{array}$ & df & $\begin{array}{c}\text { Mean } \\
\text { Square }\end{array}$ & F & Sig. \\
\hline \multirow{4}{*}{1} & Regression & 811,734 & 2 & 405,867 & 31,556 &, $000^{\mathrm{b}}$ \\
\cline { 2 - 8 } & Residual & 334,404 & 26 & 12,862 & & \\
\cline { 2 - 8 } & Total & 1146,138 & 28 & & & \\
\hline
\end{tabular}

a.Dependent Variable: Kualitas layanan pustakawan

b.Predictors: (Constant), kmpetensi pustakawan, motivasi pustakawan

Sumber: Data Primer Hasil Olahan SPSS, Tahun 2015
Hasil ini sesuai dengan penelitian sebelumnya (Assiri, 2015) yang menyatakan bahwa kompetensi dan motivasi secara simultan berpengaruh signifikan terhadap kinerja pustakawan Universitas Hasanudin. Artinya tinggi rendahnya kinerja sangat ditentukan oleh kompetensi dan motivasi kerja yang dimiliki oleh setiap staf. Semakin naik kompetensi dan motivasi yang dimiliki oleh staff semakin meningkat pula hasil kinerja pustakawan. Berdasarkan hasil diskusi dengan penelitian sebelumnya maka dapat disimpulkan bahwa pengaruh motivasi kerja dan kompetensi professional terhadap kualitas layanan secara simultan signifikan. Artinya baik buruknya suatu kualitas layanan selalu ditentukan oleh motivasi kerja dan kompetensi profesional yang dimiliki oleh staf yang ada.-Apabila motivasi kerja tinggi dan kompetensi professional baik maka kualitas layanan dari setiap staf akan baik.

\section{b. Pengaruh Relatif Motivasi Terhadap Kualitas Layanan}

Dalam penelitian ini yang dimaksud pengaruh relatif yaitu pengaruh parsial variabel bebas yang terdiri dari variabel $\left(\mathrm{X}_{1}\right)$ motivasi pustakawan, variabel $\left(\mathrm{X}_{2}\right)$ kompetensi pustakawan terhadap variabel terikat (Y) kualitas layanan pustakawan dalam melakukan aktifitas kepustakawanan. Keberadaan pengaruh dapat dilihat pada hasil uji t hitung tampak pada tabel 4 nilai thitung sebesar 0.832 dengan nilai probabilitas signifikan variabel motivasi kerja sebesar 0.413 lebih besar dari pada 0.05 atau $(0.413>0.05)$ nilai ini mempunyai arti bahwa pengaruh variabel motivasi kerja terhadap variabel kualitas layanan tidak signifikan.

Tabel 4 Uji Signifikan t

\begin{tabular}{|c|c|c|c|c|c|c|c|c|}
\hline & \multirow{2}{*}{ Model } & \multicolumn{2}{|c|}{$\begin{array}{l}\text { Unstandardized } \\
\text { Coefficients }\end{array}$} & \multirow{2}{*}{$\begin{array}{c}\begin{array}{c}\text { Standardized } \\
\text { Coefficients }\end{array} \\
\text { Beta }\end{array}$} & \multirow{2}{*}{$\mathrm{t}$} & \multirow{2}{*}{ Sig. } & \multicolumn{2}{|c|}{$\begin{array}{l}\text { Collinearity } \\
\text { Statistics }\end{array}$} \\
\hline & & B & Std. Error & & & & Tolerance & VIF \\
\hline \multirow{3}{*}{1} & (Constant) & 6,756 & 7,659 & &, 882 & ,386 & & \\
\hline & Motivasi & ,167 & 201 & , 125 &, 832 & ,413 & ,496 & 2,017 \\
\hline & Kompetensi & ,633 & ,127 & ,748 & 4,972 &, 000 & ,496 & 2,017 \\
\hline
\end{tabular}

Dependent Variabel: Kualitas Layanan Pustakawan Sumber: Data Primer Hasil Olahan SPSS, Tahun 2015 
Hasil tersebut berlawanan dengan penelitian sebelumnya (Wiranto, dkk, 2015) yang menyatakan adanya pengaruh signifikan motivasi terhadap kinerja pustakawan. Semakin meningkat motivasi kerja hasil kinerja pustakawan semakin tinggi. Ini menunjukkan ketidak sesuaian terhadap hasil penelitian sebelumnya, bahwa motivasi kerja mempunyai pengaruh signifikan terhadap kinerja. Bahkan menurut hasil penelitian sebelumnya tinggi rendahnya kinerja pustakawan dapat dijelaskan melalui motivasi kerja. Berdasarkan hasil penelitian maka dapat disimpulkan bahwa pengaruh motivasi kerja terhadap kualitas layanan secara parsial tidak signifikan. Artinya meskipun ada kenaikan satu tingkat motivasi kerja maka kualitas layanan, apabila tidak ada faktor lain yang mendukung maka secara parsial motivasi kerja tidak dapat digunakan untuk menjelaskan kualitas layanan.

Demikian juga, secara parsial koefisien jalur pengaruh sumbangan relatif variabel bebas $\left(X_{1}\right)$ motivasi kerja pustakawan terhadap variabel terikat (Y) kualitas layanan pustakawan sebesar $12,5 \%$. Kecilnya sumbangan relatif ini mengindikasikan rendahnya motivasi kerja pustakawan dalam melaksanakan berbagai tugas kepustakawanan. Hal ini terlihat pada tabel 1 sebanyak 29 terdapat 16 responden motivasinya rendah bahkan ada yang sangat rendah. Hanya 13 responden saja yang mempunyai motivasi tinggi dan sangat tinggi. Artinya 55\% motivasi kerja pustakawan melebihi dari nilai rata-rata mempunyai motivasi rendah dan hanya $45 \%$ saja yang mempunyai motivasi kerja tinggi. Rendahnya motivasi kerja ini disebabkan oleh berbagai faktor diantaranya: (1) kurangnya kemandirian pustakawan dalam meningkatkan kompetensi profesional guna memperlancar berbagai aktifitas tugas kepustakawanan; (2) masih rendahnya rasa tanggungjawab pustakawan terhadap tugas yang dikerjakan; (3) lemahnya keinginan berprestasi sesama pustakawan dan juga profesi lain; (4) lemahnya minat baca pustakawan, sehingga mengalami kesulitasn dalam mengembangkan diri.

\section{d. Pengaruh Relatif Kompetensi Terhadap Kualitas Layanan}

Dalam penelitian diatas yang dimaksud pengaruh relatif yaitu pengaruh parsial variabel bebas yang terdiri dari variabel $\left(\mathrm{X}_{1}\right)$ motivasi pustakawan, variabel $\left(\mathrm{X}_{2}\right)$ kompetensi pustakawan terhadap variabel terikat (Y) kualitas layanan pustakawan dalam melakukan aktifitas kepustakawanan. Keberadaan pengaruh dapat dilihat pada hasil uji t hitung seperti tampak pada tabel 4 tertera nilai thitung untuk sebesar 4,972 dengan nilai probabilitas signifikan variabel kompetensi pustakawan sebesar 0.000 lebih kecil dari pada 0.05 atau $(0.000<0.05)$ nilai ini mempunyai arti bahwa pengaruh variabel kompetensi pustakawan terhadap variabel kualitas layanan signifikan. Sehingga variabel bebas kompetensi pustakawan secara parsial mempunyai pengaruh signifikan terhadap variabel terikat kualitas layanan pustakawan. Hasil ini sesuai penelitian (Diyah Kartikasari, 2012) yang menemukan adanya pengaruh signifikan variabel kompetensi terhadap kinerja pustakawan. Artinya baik dan buruknya kualitas layanan pustakawan juga ditentukan oleh kompetensi pustakawan. Semakin baik kompetensi pustakawan, maka hasil kinerja pustakawan di perpustakaan akan semakin baik. Begitu juga sebaliknya apabila kompetensinya kurang, maka kinerja pustakawan di perpustakaan akan menurun. Hal ini disebabkan oleh berbagai faktor yang ikut mempengaruhi tingkat kemampuan kompetensi pustakawan diantaranya yaitu: keterampilan dan kreatifitas serta kecerdasan pustakawan, komunikasi dan tanggapan pustakawan, keramahan dan rasa simpati pustakawan terhadap pemustaka. Hasil penelitian lainya yang sesuai (Pamunkas, dkk, 2015 ) menyatakan bahwa kompetensi professional mempunyai pengaruh signifikan terhadap prestasi kerja. Hasil tersebut menyatakan bahwa secara bersama-sama pengetahuan, ketrampilan interpersonal, dan sikap yang menjadi dasar dari pada professionalisme seorang pustakawan berpengaruh terhadap prestasi kerja. Artinya tinggi rendahnya prestasi kerja sangat ditentukan oleh kompetensi pustakawan. 
Berdasarkan kedua hasil penelitian di atas maka dapat disimpulkan bahwa pengaruh kompetensi pustakawan terhadap kualitas layanan secara parsial signifikan. Artinya meskipun ada kenaikan satu tingkat kompetensi pustakawan maka kualitas layanan akan meningkat. Sehingga secara parsial peningkatan kualitas layanan dapat dijelaskan melalui kompetensi profesional.

Demikian juga, secara parsial seperti tercantum pada tabel 2 besarnya sumbangan relatif variabel bebas $X_{2}$ (kompetensi pustakawan) terhadap variabel terikat $\mathrm{Y}$ (kualitas layanan pustakawan) yaitu $74,8 \%$. Besarnya sumbangan relatif ini mengindikasikan tingginya kompetensi yang dimiliki pustakawan. Hal ini tampak sebagaimana pada Tabel 1 sebanyak 29 responden terdapat 15 responden yang mempunyai kompetensi pustakawan tinggi dan sisanya 14 responden kurang professional. Artinya 52\% lebih besar dari jumlah rata-rata mempunyai kompetensi pustakawan tinggi (baik) dan hanya $48 \%$ saja yang mempunyai nilai rendah.

\section{E. KESIMPULAN}

\section{a) Kesimpulan}

Setelah dilakukan analisa uji statistik dan pembahasan secara mendalam maka dapat disimpulkan sebagai berikut:

1. Motivasi pustakawan secara parsial tidak berpengaruh signifikan terhadap kualitas layanan pustakawan dengan sumbangan relatif sebesar $12,5 \%$.

2. Kompetensi pustakawan secara parsial berpengaruh signifikan terhadap kualitas layanan pustakawan dengan sumbangan relatif sebesar $74,8 \%$.

3. Kompetensi profesional dan motivasi kerja secara stimulat (?) berpengaruh signifikan terhadap kualitas layanan dengan sumbangan efektif sebesar $84,2 \%$.

\section{b) Saran}

Berdasarkan kesimpulan di atas, maka peneliti mengajukan saran sebagai berikut:

1. Pimpinan harus meningkatkan motivasi pustakawan untuk mewujudkan layanan berkualitas.

2. Kompetensi pustakawan lebih ditingkatkan semaksimal mungkin untuk meningkatkan kualitas layanan.

3. Peningkatan motivasi dan kompetensi pustakawan lebih baik dilakukan bersamaan.

\section{DAFTAR PUSTAKA}

Ajis. (2008). Pengaruh motivasi kerja pegawai terhadap kualitas pelayanan penerbitan KK dan KTP di Kecamatan Karimun (Studi Kelembagaan Siak). Tesis, Jakarta: Program Studi Magister Administrasi Publik Universitas Terbuka, diakses pada t a $n$ g g a $14-4-2014$ d a r i www.pustaka.ut.ac.id/.../index.php.

Assiri, Annis (2015) Pengaruh Kompetensi, Motivasi terhadap Kinerja Pegawai UPT Perpustakaan Universitas Hasanuddin diakses 12-10-2015 dari http:// repository.unhas.ac.id/handle/123456789/ 14982

Daryono. (2010). Kompetensi Pustakawan Dalam Memberikan Layanan Prima di Perpustakaan Perguruan Tinggi, "Jurnal Kepustakawanan dan Masyarakat Membaca”. Vol.26 No.2, Juli-Desember.

Herdian Dito, Anok ( 2010), Pengaruh Kompensasi Terhadap Kinerja Karyawan Pt. Slamet Langgeng Purbalingga Dengan Motivasi Kerja Sebagai Variabel Intervening, Fakultas Ekonomi Universitas Diponegoro Semarang. Diakses 4-8-2016 dari https:// core.ac.uk/download/files/379/11722267.

Hermawan, Rachman \& Zen Zulfikar. (2006), Etika Kepustakawanan. Sagung Seto, Jakarta. 
Kartikasari, Diyah.(2012). Pengaruh Kompetensi Pustakawan Terhadap Kinerja Perpustakaan di Upt Perpustakan Universitas Negeri Semarang, Semarang., “ ejournal Vol 1, No 1(2012)".: Program Studi Ilmu Perpustakaan, Universitas Diponegoro ( UNDIP ), Semarang. Diakses tanggal 8-10-2015 dari http://ejournal-s1.undip.ac.id.

Kismiyati, Titiek (2011), Kesiapan Sertifikasi Pustakawan. Diakses tanggal 9-10-2015 dari https://ipijogja.files.wordpress.com

Lasa, Hs. (2009). Kamus Kepustakawanan Indonesia. Pustaka Book Publisher. Yogyakarta.

Maslow, Abraham H. (1994). Motivasi dan Kepribadian (Teori Motivasi dengan Pendekatan Hierarki Kebutuhan Manusia).

Pamungkas, Lucky Dewi, dkk (2015) Pengaruh Kompetensi Pustakawan Terhadap Prestasi Kerja (Studi pada Perpustakaan Universitas Brawijaya), "Jurnal Administrasi Publik (JAP)". Vol. 3, No. 5, Hal. 739-744, Jurusan Administrasi Publik, Fakultas Ilmu Administrasi, Universitas Brawijaya, Malang. Diakses $\mathrm{t}$ a $\mathrm{n} g \mathrm{~g}$ a $16-10-2015 \mathrm{~d}$ a $\mathrm{r}$ i http://administrasipublik.studentjournal. ub.ac.id
Samosir, Jhon Hermanto (2006). Pengaruh Kemampuan Dan Motivasi Kerja Perawat Terhadap Pelaksanaan Kualitas Pelayanan Kesehatan Pada Rumah Sakit Bethesda Yogyakarta. Tesis, Yogyakarta: Duta Wacana Christian University, diakses pada tanggal 4-4-2015 dari http://sinta.ukdw.ac.id.

Sampe, Maria Lobon. (2014), Pengaruh Kompetensi Terhadap Kinerja Pustakawan Universitas Hasanuddin, diakses pada tanggal 2-3-2015 dari http://repository.unhas.ac.id/Discover.

Supriyanto. (2001). Pengaruh Kemampuan dan Motivasi Kerja Dosen Terhadap Kualitas Layanan Kepada Mahasiswa Jurnal Manajemen Bisnis, 66. Volume 16. No. 01. Ed. April 2011. Ejournal.umm.ac.id/. Diunduh tanggal 23-2-1025.

Tjiptono, Fandy. (2003). Prinsip-Prinsip Total Quality Service: -ed. V, Andi. Yogyakarta.

Undang-Uudang Republik Indonesia Nomor 43 Tahun 2007 Tentang Perpustakaan.

Tritawirasta, Wiratna. (2010). Strategi Pembinaan Pustakawan Dalam Pengelolaan Perpustakaan Elektronik: Jurnal Pustakawan Indonesia Volume 10 No. 1(2010).

http://journal.ipb.ac.id/index.php/jpi/article/vie w. Diunduh pada tanggal 2-4-2015. 